\title{
Interference Between D and M Types of Plum pox virus in Japanese Plum Assessed by Specific Monoclonal Antibodies and Quantitative Real-Time Reverse Transcription-Polymerase Chain Reaction
}

\author{
Nieves Capote, M. Teresa Gorris, M. Carmen Martínez, Margarita Asensio, Antonio Olmos, and Mariano Cambra
}

Instituto Valenciano de Investigaciones Agrarias (IVIA), Departamento Protección Vegetal y Biotecnología, Carretera Moncada-Náquera km 5, 46113 Moncada, Valencia, Spain.

Accepted for publication 23 November 2005.

\begin{abstract}
Capote, N., Gorris, M. T., Martínez, M. C., Asensio, M., Olmos, A., and Cambra, M. 2006. Interference between D and M types of Plum pox virus in Japanese plum assessed by specific monoclonal antibodies and quantitative real-time reverse transcription-polymerase chain reaction. Phytopathology 96:320-325.

The dynamics of virus interference between two isolates of Plum pox virus (PPV) belonging to the main PPV types, D and M, were analyzed in Japanese plum (Prunus salicina) by challenge inoculations. To assess the consequences of a PPV-M infection on plum already infected with PPV$\mathrm{D}$, and vice versa (predominance of one of the strains, recombination, synergism, symptoms aggravation, and so on), 30 Japanese plum trees were graft inoculated with PPV-D or PPV-M isolates in quarantine conditions. One year postinoculation, in the event that the inoculated isolates were detected in the whole plant, a second challenge inoculation

specific monoclonal antibodies. Reverse transcription-polymerase chain reaction (RT-PCR) with D- and M-specific primers confirmed the serological typing. Real-time RT-PCR assays were performed using D- and M-specific fluorescent 3' minor groove binder-DNA probes, which were able to detect and quantify PPV populations in the inoculated plants with greater precision. The presence of PPV-D in Japanese plum did not crossprotect the trees against PPV-M infection. In PPV-D-infected plants, the PPV-M strain used as challenge inoculum behaved differently depending on the plum cultivar assayed. In cv. Black Diamond, PPV-M invaded the plant progressively, displacing the previous PPV-D population; whereas, in cv. Sun Gold, both PPV isolates coexisted in the plant. In contrast, the PPV-D isolate used was unable to infect plants of both cultivars in which a PPV-M population already was established. After 7 years, no synergism was observed and no recombination event between PPV-D and PPV-M genomes was detected.
\end{abstract} (PPV-M or PPV-D, respectively) was performed by grafting. The presence of PPV-D, PPV-M, or both was monitored for 7 years by doubleantibody sandwich indirect enzyme-linked immunosorbent assay using
Additional keywords: interaction, MGB probes, sharka.
Plum pox virus (PPV) is the causal agent of sharka disease, which causes severe damage and important economic losses in the stone fruit industry. The disease mainly affects apricot, plum, and peach. The genus Potyvirus was first detected in Bulgaria in 1917 (2); since then, it has spread to most of eastern and central Europe and the Mediterranean basin. More recently, PPV has spread to the Americas, occurring in Chile (30), the United States (21), Canada (32), and Argentina (J. Ortego, personal communication). PPV is transmitted by a number of aphid species in a noncirculative, nonpersistent manner $(20,25)$. PPV also is transmitted by grafting, whereby the introduction of infected plant material for vegetative propagation facilitated PPV dispersal over long distances. Four main PPV groups with different biological, serological, molecular, and epidemiological characteristics have been described: PPV-D (Dideron), PPV-M (Marcus), PPV-EA (El Amar), and PPV-C (Cherry) $(9,12,23,24,27)$. In addition, two new PPV groups have been proposed: PPV-W (18) and PPV-Rec (Recombinant) (16). Among these, PPV types D and M are the most prevalent (22).

The Japanese plum (Prunus salicina Lindl.) industry is economically important in countries surrounding the Mediterranean basin, as well as in areas with a temperate climate such as California (United States), Chile, South-Africa, and Australia. P. salicina is a natural host of PPV and displays different levels of

Corresponding author: M. Cambra; E-mail address: mcambra@ivia.es

DOI: 10.1094/PHYTO-96-0320

(C) 2006 The American Phytopathological Society susceptibility depending on the cultivar (7). PPV-D is the only type currently present in Spain, Chile, and, to a lesser extent, the United States. However, Spain in particular is at high risk of being affected by the aggressive PPV-M type, which presently is spreading through Mediterranean countries. This is due to the traffic of infected plant material and because PPV-M is more readily vector transmitted. In 2002, PPV-M was detected and successfully eradicated in Spain (6).

Mixed virus infections commonly occur in higher plants. The interaction between co-infecting viruses has been studied extensively. Specifically, members of the genus Potyvirus interact with a broad range of unrelated viruses, including members of the genus Potexvirus (e.g., Potato virus X) (13,17,29), Pararetrovirus (e.g., Cauliflower mosaic virus) (19), Picornavirus (e.g., Cowpea mosaic virus) (1), and other potyviruses (e.g., Tobacco vein mottling virus, Tobacco etch virus, and Pepper mottle virus) (33), producing in such cases synergistic diseases. On the other hand, Dietrich and Maiss (13) demonstrated no synergism and spatial separation of co-inoculated Potyvirus (PPV, Tobacco vein mottling virus, and Clover yellow vein virus) populations of the same or different strain in Nicotiana benthamiana Domin. plants.

Challenge experiments were performed to analyze the consequences of PPV-M superinfection on Japanese plum trees previously infected with PPV-D and vice versa. The development of the two inoculated virus populations and the interaction between them were studied over a 7-year period. Additionally, sensitive molecular techniques were used, such as quantitative real-time reverse transcription-polymerase chain reaction (RT-PCR), with fluorescent 3' minor groove binder (MGB) DNA-specific Taqman 
probes to achieve accurate detection, differentiation, and quantification of PPV-D and PPV-M virus populations in the same plant. In a previous real-time multiplex RT-PCR assay, SYBR Green technology was used to detect and differentiate PPV-D and PPV$M$ types in woody and herbaceous plants (34). Taqman technology also has been used for universal detection and quantification of PPV (26).

Cross-protection against aggressive isolates of Citrus tristeza virus (CTV) constitutes a common agronomic practice in citrus nurseries in Brazil (11); however, to our knowledge, this is the first time that the interference between two groups of the same virus has been monitored in stone fruit trees in a long-term assay.

\section{MATERIALS AND METHODS}

Host plants, PPV isolates, and inoculation assays. Two-yearold Japanese plum cvs. Black Diamond and Sun Gold were grown in the open field under insect-proof facilities (quarantine screenhouse) at Instituto Valenciano de Investigaciones Agrarias (IVIA) in Valencia, Spain. In all, 10 Black Diamond trees were chip (nonbudding) graft inoculated with a GF305 peach seedling infected with a well-characterized PPV-D isolate $(3.3 \mathrm{RB} / \mathrm{GF}$; AF172346) and another 10 trees were graft inoculated with a typical PPV-M isolate (MS89 Mp11/GF) following the same procedure. In the same way, five Sun Gold trees were inoculated with the previously mentioned PPV-D isolate and another five trees with PPV-M. In previous experiments, both PPV isolates showed similar double-antibody sandwich indirect enzyme-linked immunosorbent assay (DASI-ELISA) values in Sun Gold plants. Graftings were performed in May 1997. One year later, the trees were assessed by DASI-ELISA (described below) using PPV universal and PPV-D- and -M-specific monoclonal antibodies. Some of the already infected trees were graft inoculated again; 7 of 15 trees previously inoculated with PPV-D were challenge inoculated with the PPV-M isolate (referred to as D+M trees), and 7 of 15 trees previously inoculated with PPV-M were challenge inoculated with the PPV-D isolate (referred to as M+D trees). The rest of the trees remained as single-inoculated controls. Three additional trees of each cultivar were not inoculated and were kept as healthy controls.

Infection monitoring. At least five symptomatic leaves were collected from each plant and $1 \mathrm{~g}$ was ground in $20 \mathrm{ml}$ (1:20, $\mathrm{wt} / \mathrm{vol}$ ) of phosphate-buffered saline buffer, $\mathrm{pH} 7.2$, supplemented with $2 \%$ (wt/vol) polyvinyl-pyrrolidone and $0.2 \%$ (wt/vol) sodium diethyl dithiocarbamate (5) inside individual plastic bags containing a thin net (Bioreba). The same crude extracts were used for both serological and molecular analyses. Total RNA was obtained from $200 \mu \mathrm{l}$ of plant extracts using the RNeasy Plant Minikit (Qiagen, Hilton, Germany) for RT-PCR and quantitative real-time RT-PCR reactions.

DASI-ELISA. Serological assays for PPV-D and PPV-M infection were performed in May 1997, 1998, 2000, 2003, and 2004 (over a 7-year experimental period) by DASI-ELISA using 5BIVIA PPV-universal monoclonal antibody (Durviz kit, Valencia,
Spain), and PPV-D (4DG5) and PPV-M (AL) typing specific monoclonal antibodies $(3,5,8)$, following the European and Mediterranean Plant Protection Organization Protocol (14).

$R T-P C R$. In May 2004 (7 years after the first inoculation), PPV populations present in plants were examined by heminested RTPCR using D- and M-specific primers $(8,27)$.

Cloning and sequencing. A 243-bp cDNA fragment from the virus populations present in six $\mathrm{D}+\mathrm{M}$ - and $\mathrm{M}+\mathrm{D}$-inoculated trees (three from Black Diamond and three from Sun Gold) were amplified by RT-PCR using P1 and P2 primers (36) and cloned into pGEM-T (Promega, Inc., Madison, WI). Eight clones from each PPV population present in a given tree were sequenced. Analyses of the sequenced fragments were performed using the similarity search tool megablast of the BLAST program from the National Center for Biotechnology Information (NCBI; Bethesda, MD).

$M G B$ probes, primers design, and quantitative real-time $R T$ $P C R$. Primers and Taqman MGB probes were designed using the Primer Express software (Applied Biosystems). PPV nucleotide sequences available in the GenBank database were aligned and used to design the forward primer PPV-MGB-F (5'-CAGACTACAGCCTCGCCAGA-3') and the reverse primer PPV-MGB-R (5'-CTCAATGCTGCTGCCTTCAT-3') to amplify a 106-bp fragment of the coat protein (CP) gene of PPV. In the same way, 6FAM dye MGB-labeled probes specific for detection of PPV-D isolates (MGB-D probe, 5'-TTCAACGACACCCGTA-3') and PPV-M isolates (MGB-M probe, 5'-TTCAACAACGCCTGTG$3^{\prime}$ ) were designed (Table 1).

To build standard curves for quantitative detections, a 243-bp fragment was amplified by RT-PCR using P1 and P2 universal primers (36) from PPV-M (PS, AJ243957) and PPV-D (3.3RB/ $\mathrm{Nb}, \mathrm{AF} 172347)$ isolates and cloned into pGEM-T in the appropriate orientation. NotI linearized plasmids were transcribed in vitro using the Megascript T7 kit (Ambion Inc., Austin, TX) to obtain 304-bp transcripts from PPV-D and PPV-M isolates, respectively. RNA concentration was determined by UV densitometry and the number of RNA molecules estimated. Tenfold serial dilutions of transcripts from $10^{8}$ to $10^{0}$ RNA molecules were used as standard curves for PPV-D or PPV-M quantitations. Quantitative real-time RT-PCR reactions were performed in an ABI Prism 7000 (Applied Biosystems) using 1× Taqman Universal PCR Master Mix (Applied Biosystems), $1 \times$ MultiScribe and RNase Inhibitor Mix (Applied Biosystems), $1 \mu \mathrm{M}$ primer MGB-F, $1 \mu \mathrm{M}$ primer MGB-R, $150 \mathrm{nM}$ MGB-D- or -M-specific probe, and $5 \mu \mathrm{l}$ of RNA sample. RT-PCR reactions were carried out at $48^{\circ} \mathrm{C}$ for $30 \mathrm{~min}$ and $95^{\circ} \mathrm{C}$ for $10 \mathrm{~min}$, followed by 40 cycles of amplification $\left(95^{\circ} \mathrm{C}\right.$ for $15 \mathrm{~s}$ and $60^{\circ} \mathrm{C}$ for $1 \mathrm{~min}$ ). Number of molecules (amplifiable PPV-RNA targets) in the samples was calculated per $5 \mu$ of RNA obtained from $200 \mu \mathrm{l}$ of infected plant extracts. Quantitative detections were performed with three independent repetitions for all samples.

Validation assays to assess the specificity of the method were performed with $12 \mathrm{PPV}-\mathrm{D}$ isolates (3.30RB/GF, 3.3RB/GF, 3.3RB/Nb, 3.4RB/GF, 1.4S, 13.3S, 16L, 32L, 85L, 15RB, B4P, and $\mathrm{K} 6 \mathrm{~F}$ ) and $12 \mathrm{PPV}-\mathrm{M}$ isolates $(6 \mathrm{M} / \mathrm{GF}, 7 \mathrm{M} / \mathrm{GF}, 9 \mathrm{M} / \mathrm{GF}$,

TABLE 1. Primers and probes used in quantitative real-time detection of Plum pox virus (PPV) and PPV-D and PPV-M type populations

\begin{tabular}{|c|c|c|c|c|c|}
\hline Primer, probe ${ }^{a}$ & Orientation & Sequence $\left(5^{\prime}-3^{\prime}\right)$ & Size & Position & Reference \\
\hline PPV-MGB-F & Forward primer & CAGACTACAGCCTCGCCAGA & 20 & $9337-9356^{\mathrm{b}}$ & This work \\
\hline PPV-MGB-R & Reverse primer & CTCAATGCTGCTGCCTTCAT & 20 & $9423-9442^{b}$ & This work \\
\hline MGB-D & MGB-TaqMan probe & TTCAACGACACCCGTA & 16 & $9383-9398^{b}$ & This work \\
\hline MGB-M & MGB-TaqMan probe & TTCAACAACGCCTGTG & 16 & $9383-9398^{c}$ & This work \\
\hline P241 & Forward primer & CGTTTATTTGGCTTGGATGGAA & 22 & $9456-9477^{b}$ & Olmos et al. 2005 \\
\hline P316D & Reverse primer & GATTAACATCACCAGCGGTGTG & 22 & $9510-9531^{\mathrm{b}}$ & Olmos et al. 2005 \\
\hline P316M & Reverse primer & GATTCACGTCACCAGCGGTGTG & 22 & $9510-9531^{\mathrm{b}}$ & Olmos et al. 2005 \\
\hline PPV-DM & TaqMan probe & CGTCGGAACACAAGAAGAGGACACAGA & 27 & $9479-9505^{b}$ & Olmos et al. 2005 \\
\hline
\end{tabular}

a $\mathrm{MGB}=$ minor groove binder.

${ }^{\mathrm{b}}$ Relative position on PPV-D accession no. AF401296.

c Relative position on PPV-M accession no. M92280. 
16M/GF, 17M/GF, 18M, 19M, 20M, 22M, MS89/GF, MS89 Mp11/GF, and PS/Nc) from different Prunus cultivars and origins. Amplifiable PPV targets in these samples were quantified using the primers and specific MGB probes designed and, in parallel, with primers and Taqman probes previously described (26) for universal detection of PPV (Table 1). To validate reliability of detecting PPV-D/PPV-M mixed infections, P1P2 transcripts from PPV-D and PPV-M isolates were used, adjusted to different PPV-D:PPV-M ratios: 1:1, 1:2, 1:3, 1:4, 1:5, 1:10, 1:100, 1:1,000, 1:10,000, and vice versa (PPV-M:PPV-D).

Recombination analyses. Two strategies were used to detect possible recombinants between PPV-D and PPV-M isolates in trees with mixed infection at the end of the experiment, 6 years after challenge inoculations: (i) RT-PCR amplification of two different regions of the PPV genome corresponding to the $\mathrm{CP}$ and the cytoplasmic inclusion protein (CI) genes, following typing techniques previously described $(8,15)$; and (ii) direct detection of recombinants by RT-PCR using a pair of primers that flank the recombination breakpoint between PPV-D and PPV-M in the 3'proximal terminus of the RNA replicase (NIb) gene (31).

\section{RESULTS}

Infection progress monitoring. The progress and development of PPV-D and PPV-M populations in single- and double-inoculated Japanese plum trees, followed by DASI-ELISA with universal and type-specific monoclonal antibodies, over a 7-year experi- mental period, is shown in Table 2. Trees of both plum cultivars inoculated with PPV-D or PPV-M became systemically infected within 1 year. The graft-inoculated isolate was distributed throughout the plant. In the trees inoculated with a single PPV isolate (D or M), only the inoculated isolate was detected throughout the experimental period. In the singly inoculated trees, PPV-D accumulated to significantly higher titers in Sun Gold than in Black Diamond trees, whereas PPV-M showed similar titers in both cultivars (Fig. 1). None of the healthy control trees were found to be infected at the end of the experiment.

In D+M Black Diamond plum trees, the aggressive PPV-M isolate progressively invaded the plant, displacing the D population. All D+M Black Diamond plum trees contained only the M type at the end of the experiment (Table 2; Fig. 1). However, all D+M Sun Gold trees remained doubly infected. In all D+M plum trees, PPV-M took at least 2 years to spread throughout the plant. On the other hand, when the first inoculum was the PPV-M isolate (M+D trees), no PPV-D was detected throughout the experimental period in either of the plum cultivars assayed. Synergism, in terms of symptom aggravation, was not observed in any of the doubleinoculated trees. Both cultivars displayed only mild symptoms of PPV infection.

RT-PCRs using P1 and P2 universal primers (data not shown) and P1 plus PPV-D- or PPV-M-specific primers were performed for all infected trees at the end of the experiment (Table 2). No discrepancies in PPV typing were observed between the serological and molecular techniques used.

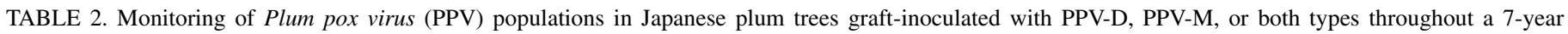
experimental period and recombination assessment ${ }^{\mathrm{a}}$

\begin{tabular}{|c|c|c|c|c|c|c|c|c|c|c|c|c|c|}
\hline \multirow[b]{2}{*}{$\operatorname{Host}^{b}$} & \multirow{2}{*}{$\frac{1997}{\text { Inoc }^{c}}$} & \multicolumn{3}{|c|}{1998} & \multicolumn{4}{|c|}{ DASI-ELISA 4DG5/AL } & \multirow{2}{*}{$\frac{2004}{\mathrm{P} 1-\mathrm{P} 2^{\mathrm{e}}}$} & \multicolumn{4}{|c|}{ RT-PCR (2004) } \\
\hline & & DE 5B-IVIA & DE 4DG5/AL & Challenge $^{\mathrm{d}}$ & 1999 & 2000 & 2003 & 2004 & & $\mathrm{P} 1(\mathrm{CP})^{\mathrm{f}}$ & CIf $(\mathrm{CI})^{\mathrm{g}}$ & $\mathrm{m} / \mathrm{m}(\mathrm{NIb})^{\mathrm{h}}$ & $\mathrm{m}-\mathrm{m}(\mathrm{NIb})^{\mathrm{i}}$ \\
\hline BD1 & PPV-D & + & $\mathrm{D}$ & $\ldots$ & $\mathrm{D}$ & $\mathrm{D}$ & $\mathrm{D}$ & $\mathrm{D}$ & $\ldots$ & $\mathrm{D}$ & $\mathrm{D}$ & $\mathrm{D}$ & - \\
\hline BD2 & PPV-D & + & $\mathrm{D}$ & $\ldots$ & $\mathrm{D}$ & $\mathrm{D}$ & $\mathrm{D}$ & $\mathrm{D}$ & $\ldots$ & $\mathrm{D}$ & $\mathrm{D}$ & $\mathrm{D}$ & - \\
\hline BD3 & PPV-D & + & $\mathrm{D}$ & $\ldots$ & $\mathrm{D}$ & $\mathrm{D}$ & $\mathrm{D}$ & $\mathrm{D}$ & $\ldots$ & $\mathrm{D}$ & $\mathrm{D}$ & $\mathrm{D}$ & - \\
\hline BD4 & PPV-D & + & $\mathrm{D}$ & $\cdots$ & $\mathrm{D}$ & $\mathrm{D}$ & $\mathrm{D}$ & $\mathrm{D}$ & $\cdots$ & $\mathrm{D}$ & $\mathrm{D}$ & $\mathrm{D}$ & - \\
\hline BD9 & PPV-D & + & D & $\ldots$ & D & D & D & D & $\ldots$ & D & D & D & - \\
\hline BD10 & PPV-D & + & D & $\ldots$ & D & $\mathrm{D}$ & D & D & $\ldots$ & $\mathrm{D}$ & D & D & - \\
\hline SG1 & PPV-D & + & D & $\ldots$ & $\mathrm{D}$ & $\mathrm{D}$ & $\mathrm{D}$ & D & $\ldots$ & D & $\mathrm{D}$ & $\mathrm{D}$ & - \\
\hline SG2 & PPV-D & + & D & $\ldots$ & D & $\mathrm{D}$ & $\mathrm{D}$ & D & $\ldots$ & D & $\mathrm{D}$ & D & - \\
\hline BD16 & PPV-M & + & M & $\ldots$ & M & M & M & M & $\ldots$ & M & M & M & - \\
\hline BD17 & PPV-M & + & M & $\ldots$ & M & M & M & M & $\ldots$ & M & M & M & - \\
\hline BD18 & PPV-M & + & M & $\ldots$ & M & M & M & M & $\ldots$ & M & M & M & - \\
\hline BD19 & PPV-M & + & M & $\ldots$ & M & M & M & M & $\ldots$ & M & M & M & - \\
\hline BD20 & PPV-M & + & M & $\ldots$ & M & M & M & M & $\ldots$ & M & M & M & - \\
\hline SG7 & PPV-M & + & M & $\ldots$ & M & M & M & M & $\ldots$ & M & M & M & - \\
\hline SG8 & PPV-M & + & M & $\ldots$ & M & M & M & M & $\ldots$ & M & M & M & - \\
\hline SG10 & PPV-M & + & M & $\ldots$ & M & M & M & M & $\ldots$ & M & M & M & - \\
\hline BD5 & PPV-D & + & D & PPV-M & $\mathrm{D}+\mathrm{M}$ & M & M & Dead & $\ldots$ & NT & NT & NT & NT \\
\hline BD6 & PPV-D & + & $\mathrm{D}$ & PPV-M & $\mathrm{D}$ & $\mathrm{D}$ & M & M & $0 \mathrm{D} / 8 \mathrm{M}$ & M & M & M & - \\
\hline BD7 & PPV-D & + & D & PPV-M & $\mathrm{D}$ & $\mathrm{D}$ & M & M & $0 \mathrm{D} / 8 \mathrm{M}$ & M & M & $\mathrm{M}$ & - \\
\hline BD8 & PPV-D & + & D & PPV-M & $\mathrm{D}$ & $\mathrm{D}+\mathrm{M}$ & $\mathrm{D}+\mathrm{M}$ & M & $0 \mathrm{D} / 8 \mathrm{M}$ & M & M & M & - \\
\hline SG3 & PPV-D & + & D & PPV-M & D & $\mathrm{D}$ & $\mathrm{D}+\mathrm{M}$ & $\mathrm{D}+\mathrm{M}$ & $1 \mathrm{D} / 7 \mathrm{M}$ & $\mathrm{D}+\mathrm{M}$ & $\mathrm{D}+\mathrm{M}$ & $\mathrm{D}+\mathrm{M}$ & - \\
\hline SG4 & PPV-D & + & D & PPV-M & $\mathrm{D}+\mathrm{M}$ & $\mathrm{D}+\mathrm{M}$ & $\mathrm{D}+\mathrm{M}$ & $\mathrm{D}+\mathrm{M}$ & $\ldots$ & $\mathrm{D}+\mathrm{M}$ & $\mathrm{D}+\mathrm{M}$ & $\mathrm{D}+\mathrm{M}$ & - \\
\hline SG5 & PPV-D & + & D & PPV-M & $\mathrm{D}$ & $\mathrm{D}$ & $\mathrm{D}$ & $\mathrm{D}+\mathrm{M}$ & $\ldots$ & $\mathrm{D}+\mathrm{M}$ & $\mathrm{D}+\mathrm{M}$ & $\mathrm{D}+\mathrm{M}$ & - \\
\hline BD11 & PPV-M & + & M & PPV-D & M & M & M & M & $\ldots$ & M & M & M & - \\
\hline BD12 & PPV-M & + & M & PPV-D & M & M & M & M & $\ldots$ & M & M & M & - \\
\hline BD13 & PPV-M & + & M & PPV-D & M & M & M & M & $\ldots$ & M & M & M & - \\
\hline BD14 & PPV-M & + & M & PPV-D & M & M & M & M & $\ldots$ & M & M & M & - \\
\hline BD15 & PPV-M & + & $\mathrm{M}$ & PPV-D & M & M & M & M & $\ldots$ & $\mathrm{M}$ & M & M & - \\
\hline SG6 & PPV-M & + & M & PPV-D & M & M & M & M & 0D/8M & M & M & M & - \\
\hline SG9 & PPV-M & + & M & PPV-D & M & M & M & M & 0D/8M & M & M & M & - \\
\hline
\end{tabular}

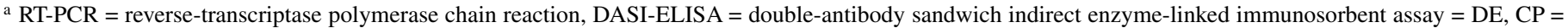
coat protein gene, $\mathrm{CI}=$ cytoplasmic inclusion protein gene, $\mathrm{NT}=$ not tested.

b Plant host: $\mathrm{BD}=$ Prunus salicina $\mathrm{cv}$. Black Diamond and $\mathrm{SG}=P$. salicina $\mathrm{cv}$. Sun Gold

${ }^{c}$ Initial inoculum: PPV-D = 3.3RB/GF and PPV-M = MS89 Mp11/GF.

d Challenge inoculum.

e P1-P2 sequenced clones.

f P1-PD/P1-PM.

g CIf-CID/CIf-CIM.

${ }^{\mathrm{h}} \mathrm{mD} 5-\mathrm{mD} 3 / \mathrm{mM} 5-\mathrm{mM} 3$.

i $\mathrm{mD} 5-\mathrm{mM} 3$. 
Recombination assays. Six years after challenge inoculations, neither assay strategy detected recombinants between PPV-D and PPV-M (Table 2). At the end of the experiment, all isolates classified as PPV-D or PPV-M by ELISA-DASI also were classified as PPV-D or PPV-M, respectively, by the RT-PCR amplification of the $\mathrm{CP}, \mathrm{CI}$, and $\mathrm{NIb}$ genes. In samples where the two populations were detected at this time (SG3, SG4, and SG5 trees), simultaneous reaction with $\mathrm{D}$ - and $\mathrm{M}$-specific monoclonal antibodies and simultaneous amplification with D- and M-specific primers were observed for the PPV genes tested. No samples amplified a product by RT-PCR using the pair of primers $\mathrm{mD} 5$ (D-specific) and $\mathrm{mM} 3$ (M-specific) for direct detection of recombinants in the NIb gene (Table 2).

Quantitation of PPV-D and PPV-M populations. Primers and D- and M-specific MGB probes were developed to detect and quantify the PPV-D or PPV-M populations present in the inoculated plants with greater precision at the end of the experiment. All PPV-D isolates from different cultivars and origins that were tested to validate the method reacted positively to the MGB-D probe but not to the MGB-M one. Likewise, the different PPV-M isolates tested were detected only with the MGB-M probe and not with the MGB-D one. The universal Taqman probe detected all
PPV samples and the same quantification results were obtained with both Taqman probes (Taqman and Taqman-MGB) (data not shown). The MGB quantitative RT-PCR method permitted detection of between $10^{1}$ and $10^{8}$ molecules of amplifiable PPV-RNA targets per reaction. The detection of PPV-D and PPV-M was successful in samples with an artificial mix of RNA transcripts from PPV-D and PPV-M in different proportions, except when the ratio exceed $1: 1,000$.

The detection and quantitation of PPV-D, PPV-M, or both populations in all trees by quantitative real-time RT-PCR using Dand M-specific MGB probes, after a 7-year growth period, is shown in Figure 1A. Real-time RT-PCR results correlated with serological data using specific monoclonal antibodies (data not shown), not only in terms of the presence or absence of the virus type but also in quantitative estimation of the respective populations in mixed infections (samples SG3, SG4, and SG5). In samples in which a single ( $\mathrm{D}$ or $\mathrm{M}$ ) population was detected by DASI-ELISA and RT-PCR at the end of the experimental period, the same population was detected by the specific MGB probe. Samples with D+M mixed infection at the end of the experiment gave positive detection results with both MGB-D and MGB-M probes. In the SG3 tree, there was significantly more PPV-M; in
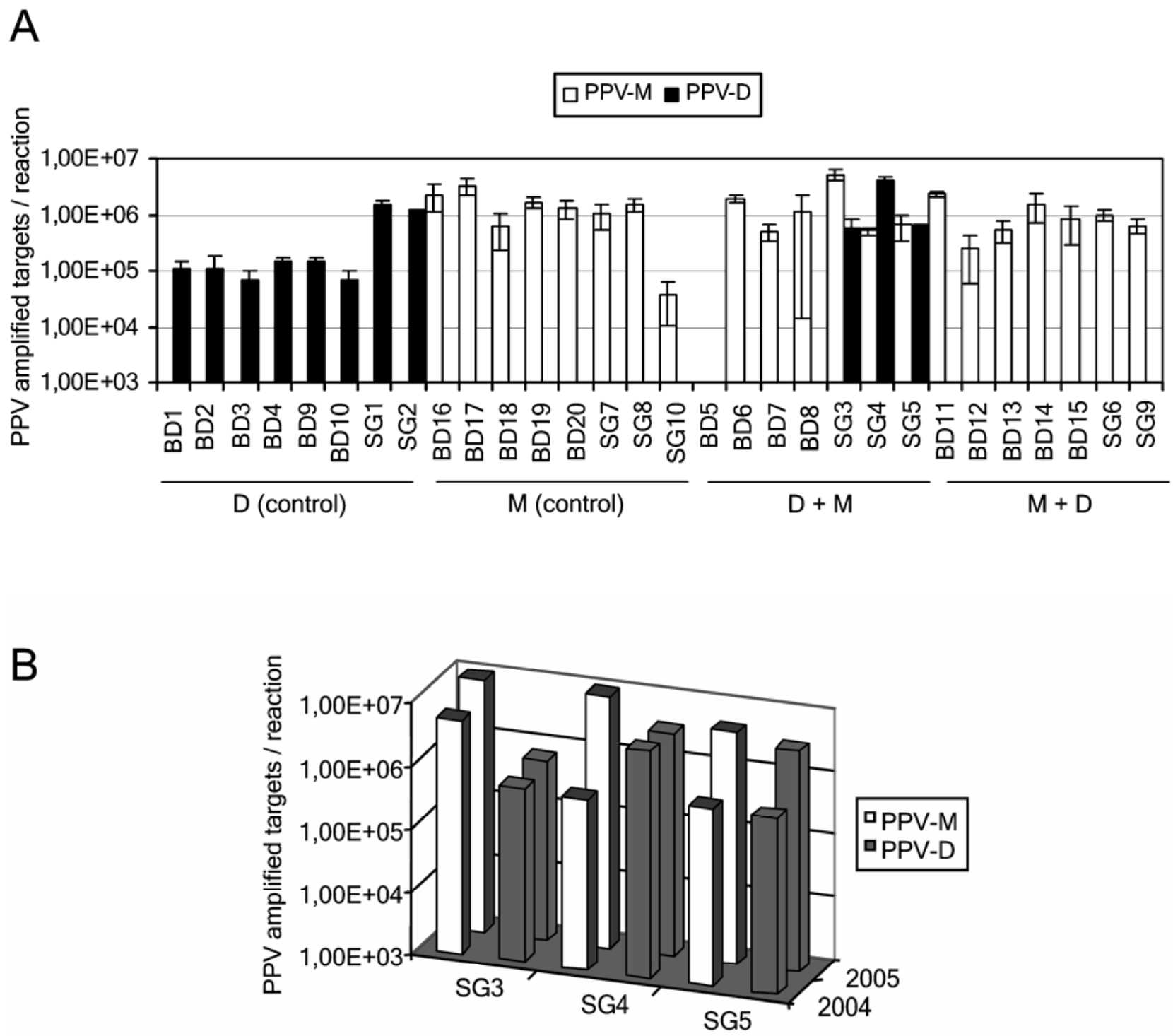

Fig. 1. A, Quantitative detection of Plum pox virus (PPV)-D and PPV-M in single and mix infected (D+M and M+D) Prunus salicina trees by real-time reverse transcription-polymerase chain reaction with minor groove binder-specific probes 7 years after the first inoculation. Quantitative data represent average results obtained from three replicates. Standard deviations are represented by bars. BD = cv. Black Diamond and SG = cv. Sun Gold. B, Evolution of PPV-D and PPV-M populations in Sun Gold trees of $P$. salicina with mixed infection during 2004 and 2005, 7 and 8 years after the first inoculation, respectively. 
the SG4 tree, there was significantly more PPV-D; and, in the SG5 tree, the two PPV types were effectively equal. Quantitative real-time RT-PCR analysis of those samples 1 year later did not show a significant predominance of either of the two PPV isolates (Fig. 1B).

Virus titer, expressed as the number of PPV-RNA-amplifiable targets, ranged from $3.7 \times 10^{4}$ to $5.2 \times 10^{6}$ molecules per RT-PCR reaction 7 years after the beginning of the experiment, although these values rose to $1.2 \times 10^{7} 1$ year later. In Sun Gold trees inoculated with only one PPV isolate, PPV-D and PPV-M populations reached approximately the same titer as those previously assessed $\left(1.35 \times 10^{6}\right.$ for PPV-D and $1.28 \times 10^{6}$ for PPV-M, except for the SG10 tree, which showed an unusually low virus titer) (Fig. 1A). However, in Black Diamond trees, virus titer at the end of the experiment was more than one order of magnitude higher for PPV-M (with an average of $1.83 \times 10^{6}$ ) than for PPV-D inoculated plants (with an average of $1.08 \times 10^{5}$ ).

\section{DISCUSSION}

The experimental approach developed in this work shows the infection dynamics of two PPV isolates belonging to the main PPV groups. Challenge inoculations by grafting a previously infected plum were used to study the interaction between PPV-D and PPV-M in Japanese plum. PPV spread throughout the whole Japanese plum tree 1 year after graft inoculation, which contrasts with the behaviour of this virus in peach and apricot trees, where PPV usually shows uneven distribution.

The presence of PPV-D did not cross-protect Japanese plum trees against PPV-M superinfection, because this strain was detected in all trees when used as challenge inoculum. Interestingly, in these cases, a delay in the infection was observed, because PPV-M took 1 year to infect a whole healthy plum but at least 2 years to become established in a tree previously infected with PPV-D.

The infection dynamics in $\mathrm{D}+\mathrm{M}$ - and $\mathrm{M}+\mathrm{D}$-inoculated trees seemed to depend on the plum cultivar assayed. All double-inoculated Black Diamond trees ended up singly infected with M, regardless of the inoculation order, indicating a clear predominance of the PPV-M type compared with the PPV-D population in this plum cultivar. Not surprisingly, PPV-M accumulated to a significantly higher titer than PPV-D in Black Diamond. In contrast, in Sun Gold, both isolates showed the same infection rate in single infections. When the first inoculum was the PPV-D isolate, PPV$M$ could infect Sun Gold and spread throughout the trees, coexisting with the previously established PPV-D type. However, PPV-D could not be detected in Sun Gold trees that previously had been infected with PPV-M. These results indicate that PPV-M prevents infection with PPV-D in the two Japanese plum cultivars studied, but that, in trees previously infected with PPV-D, the aggressive PPV-M type could either completely displace (in Black Diamond) or coexist (in Sun Gold) with the PPV-D population.

MGB real-time RT-PCR has been demonstrated as both a simple and reliable technique to detect, differentiate, and quantify PPV-D and PPV-M in woody plant material. The method was found to be very sensitive, detecting $\approx 10$ amplifiable PPV targets per RT-PCR reaction. However, detection of both types by this technique was unreliable when relative titer exceeded a ratio of $1: 1,000$. This limitation is due to competition between templates for the same pair of primers and the exponential amplification of the target sequences. This is a common phenomenon in PCR experiments using the same pair of primers in samples containing a mix of templates. Therefore, we cannot rule out the presence of very low titers of PPV-D in some of the double-inoculated trees. Nevertheless, all serological and molecular methods used in this study strongly support the prevalence of the PPV-M population in all double-inoculated plants in which the $\mathrm{M}$ type previously was established. The results also demonstrated a different fitness of the two PPV types (replacement or coexistence) in previously Dinfected trees that was dependent of the host cultivar infected.

Recombination, heteroencapsidation, or complementation between two isolates of the same virus or two different viruses are well-characterized interactions $(4,10,15,28,35)$ that imply the simultaneous presence of the two viruses in the same cell. Frequent and closely related recombinant isolates between PPV-D and PPV-M have been detected in several central- and easternEuropean countries. These natural recombinants share a recombination break point located in the $3^{\prime}$ end of the NIb gene $(15,16)$. However, in our experiment, coexistence of the two PPV types in the same plum tree throughout the 6-year experimental period did not result in the emergence of natural recombinants.

PPV-M is a serious threat to stone fruit production. Our study indicates that PPV-M superinfection can result in replacement of a previous PPV-D population or in the coexistence of the two PPV types in the same tree. Japanese plum trees frequently are infected with PPV-D in Spain and Chile. The majority of Japanese plum cultivars show little or no symptoms in fruit (6). Consequently, growers are not eradicating this type of PPV from Japanese plum and the virus is spreading from these usually symptomless reservoir trees to healthy ones. In the near future, the great majority of Japanese plum production will be based on PPV-D infected trees grown in large areas along the Mediterranean basin and in South America. This situation will not result in cross-protection against PPV-M infection.

\section{ACKNOWLEDGMENTS}

This work has been supported by grants from the Ministerio de Educación y Ciencia, INIA projects SC98-060, RTA03-099, and RTA0500190 .

\section{LITERATURE CITED}

1. Anjos, J. R., Jarlfors, U., and Ghabrial, S. A. 1992. Soybean mosaic potyvirus enhances the titer of two comoviruses in dually infected soybean plants. Phytopathology 82:1022-1027.

2. Atanassov, D. 1932. Plum pox. A new virus disease. Ann. Univ. Sofía Fac. Agric. Silvicult. 11:49-69.

3. Boscia, D., Zeramdini, H., Cambra, M., Potere, O., Gorris, M. T., and Myrta, A. 1997. Production and characterization of a monoclonal antibody specific to the $\mathrm{M}$ serotype of plum pox potyvirus. Eur. J. Plant Pathol. 103:447-480.

4. Callaway, A. S., George, C. G., and Lommel, S. A. 2004. A Sobemovirus coat protein gene complements long-distance movement of a coat proteinnull Dianthovirus. Virology 330:186-195.

5. Cambra, M., Asensio, M., Gorris, M. T., Pérez, E., Camarasa, E., García, J. A., López-Moya, J. J., López Abella, D., Vela, C., and Sanz, A. 1994. Detection of plum pox potyvirus using monoclonal antibodies to structural and non structural proteins. Bull. OEPP/EPPO Bull. 24:569-577.

6. Cambra, M. A., Crespo, J., Gorris, M. T., Martínez, M. C., Olmos, A., Capote, N., and Cambra, M. 2004. Detection and eradication of Plum pox virus Marcus type in Aragón (Spain). Acta Hortic. 657:231-235.

7. Cambra, M., Gorris, M. T., Capote, N., Asensio, M., Martínez, M. C., Bertolini, E., Collado, C., Hermoso de Mendoza, A., Mataix, E., and López, A. 2004. Epidemiology of Plum pox virus in Japanese plums in Spain. Acta Hortic. 657:195-200.

8. Candresse, T., Cambra, M., Dallot, S., Lanneau, M., Asensio, M., Gorris, M. T., Revers, F., Macquaire, G., Olmos, A., Boscia, D., Quiot, J. B., and Dunez, J. 1998. Comparison of monoclonal antibodies and polymerase chain reaction assays for the typing of isolates belonging to the $\mathrm{D}$ and $\mathrm{M}$ serotypes of plum pox potyvirus. Phytopathology 88:198-204.

9. Candresse, T., Macquaire, G., Lanneau, M., Bousalem, M., Wetzel, T., Quiot-Dounie, L., Quiot, J. B., and Dunez, J. 1994. Detection of plum pox potyvirus and analysis of its molecular variability using immunocapturePCR. Bull. OEPP/EPPO Bull. 24:585-594.

10. Cervera, M. T., Riechmann, J. L., Martín, M. T., and García, J. A. 1993. 3 -terminal sequence of the plum pox virus PS and o6 isolates: Evidence for RNA recombination within the potyvirus group. J. Gen. Virol. 74:329334.

11. Costa, A. S., and Müller, G. W. 1980. Tristeza control by cross protection. Plant Dis. 6:538-541. 
12. Crescenzi, A., d'Aquino, L., Comes, S., Nuzzaci, M., Boscia, D., Piazolla, P., and Hadidi, A. 1997. Characterization of the sweet cherry isolate of plum pox potyvirus. Plant Dis. 81:711-714.

13. Dietrich, C., and Maiss, E. 2003. Fluorescent labelling reveals spatial separation of potyvirus populations in mixed infected Nicotiana benthamiana plants. J. Gen. Virol. 84:2871-2876.

14. EPPO. 2004. Diagnostic protocol for regulated pests. Plum pox potyvirus. Bull. OEPP/EPPO Bull. 34:247-256.

15. Glasa, M., Marie-Jeanne, V., Labonne, G., Šubr, Z., Kúdela, O., and Quiot, J. B. 2002. Natural population of recombinant Plum pox virus is stable and competitive under field conditions. Eur. J. Plant Pathol. 108:843-853.

16. Glasa, M., Palkovics, L., Komínek, P., Labonne, G., Pittnerová, S., Kúdela, O., Candresse, T., and Šubr, Z. 2004. Geographically and temporally distant natural recombinant isolates of Plum pox virus (PPV) are genetically very similar and form a unique PPV subgroup. J. Gen. Virol. 85:2671-2681.

17. Goodman, R. M., and Ross, A. F. 1974. Independent assembly of virions in tobacco doubly infected by potato virus $\mathrm{X}$ and potato virus $\mathrm{Y}$ or tobacco mosaic virus. Virology 59:314-318.

18. James, D., and Varga, A. 2004. Preliminary molecular characterization of Plum pox potyvirus isolate W3174: Evidence of a new strain. Acta Hortic. 657:177-182.

19. Khan, M. A., and Demski, J. W. 1982. Identification of turnip mosaic and cauliflower mosaic viruses naturally infecting collards. Plant Dis. 66:253256.

20. Kunze, L., and Krczal, H. 1971. Transmission of sharka virus by aphids. Ann. Phytopathol. Hors Serie 255-260.

21. Levy, L., Damsteegt, V., and Welliver, R. 2000. First report of Plum pox virus (Sharka disease) in Prunus persicae in the United States. Plant Dis. 84:202.

22. López-Moya, J. J., Fernández-Fernández, M. R., Cambra, M., and García, J. A. 2000. Biotechnological aspects of plum pox virus. J. Biotechnol. 76:121-136.

23. Myrta, A., Potere, O., Boscia, D., Candresse, T., Cambra, M., and Savino, V. 1998. Production of a monoclonal antibody specific to the El Amar strain of plum pox virus. Acta Virol. 42:248-250.
24. Nemchinov, L., Hadidi, A., Maiss, H., Cambra, M., Candresse, T., and Damsteegt, V. 1996. Sour cherry strain of plum pox potyvirus (PPV): Molecular and serological evidence of a new subgroup of PPV strains. Phytopathology 86:1215-1221.

25. Ng, J. C. K., and Perry, K. L. 2004. Transmission of plant viruses by aphid vectors. Mol. Plant Pathol. 5:505-511.

26. Olmos, A., Bertolini, E., Gil, M., and Cambra, M. 2005. Real-time assay for quantitative detection of non-persistently transmitted Plum pox virus RNA targets in single aphids. J. Virol. Methods 128:151-155.

27. Olmos, A., Cambra, M., Dasí, M. A., Candresse, T., Esteban, O., Gorris, M. T., and Asensio, M. 1997. Simultaneous detection and typing of plum pox potyvirus (PPV) isolates by Heminested-PCR and PCR-ELISA. J. Virol. Methods 68:127-137.

28. Querci, M., Owens, R. A., Bartolini, I., Lazarte, V., and Salazar, L. F. 1997. Evidence for heterologous encapsidation of potato spindle tuber viroid in particles of potato leafroll virus. J. Gen. Virol. 78:1207-1211.

29. Rochow, W. F., and Ross, A. F. 1955. Virus multiplication in plants doubly infected by potato viruses $\mathrm{X}$ and Y. Virology 1:10-27.

30. Roy, A. S., and Smith, I. M. 1994. Plum pox situation in Europe. OEPP/EPPO Bull. 24:515-523.

31. Šubr, Z., Pittnerova, S., and Glasa, M. 2004. A simplified RT-PCR-based detection of recombinant Plum pox virus isolates. Acta Virol. 48:173-6.

32. Thompson, D., McCann, M., McLeod, M., Lye, D., Green, M., and James D. 2001. First report of plum pox potyvirus in Canada. Plant Dis. 85:97.

33. Vance, V. B., Berger, P. H., Carrington, J. C., Hunt, A. G., and Shi, X. M. 1995. 5' Proximal potyviral sequences mediate potato virus W potyviral synergistic disease in transgenic tobacco. Virology 206:583-590.

34. Varga, A., and James, D. 2005. Detection and differentiation of Plum pox virus using real-time multiplex PCR with SYBR Green and melting curve analysis: A rapid method for strain typing. J. Virol. Methods $123: 213-220$.

35. Vigne, E., Komar, V., and Fuchs, M. 2004. Field safety assessment of recombination in transgenic grapevines expressing the coat protein gene of Grapevine fanleaf virus. Transgenic Res. 13:165-179.

36. Wetzel, T., Candresse, T., Ravelonandro, M., and Dunez, J. 1991. A polymerase chain reaction assay adapted to plum pox potyvirus detection. J. Virol. Methods 33:355-365. 